\title{
MASALAH PEMENUHAN KEBUTUHAN AIR BERSIH TIGA DESA DI KABUPATEN ENDE
}

\author{
Oleh: \\ P. Nugro Rahardjo \\ Pusat Teknologi Lingkungan - BPPT
}

\begin{abstract}
Clean water supply is still a very difficult problem for small villages, especially in County Ende, NTT. Three villages, ie Detukeli, Ndetundora I and Ndetundora II, are the examples. The real problem is the settlement living in the area which do not have enough potential of water resources. There are some potential surface water resources, but they are located more than $3 \mathrm{~km}$ from the village settlement. One of the potential rivers is so separated by a big hill, that the people have to walk for a long distance to reach the clean water resource. To solve the problem, it is very important to develop a transmition piping, including the distribution net and a hidram water pumping system. To construct a complete water supply system needs a lot of investation. For only Village Detukeli as an example, it needs approximately almost 2 thousand million rupiahs.
\end{abstract}

Kata Kunci : Clean water supply, limited potential of water resources

\section{PENDAHULUAN}

\subsection{Latar Belakang}

Air bersih merupakan kebutuhan pokok bagi kehidupan manusia. Karena itu kriteria terpenuhinya kebutuhan air bersih bagi suatu masyarakat tertentu menjadi suatu acuan dalam menentukan apakah masyarakat di suatu lokasi atau desa sudah cukup sejahtera atau belum. Propinsi Nusa Tenggara Timur termasuk dalam Kawasan Indonesia Timur yang dalam periode Program Jangka Panjang Tahap II (PJPT II) telah ditetapkan oleh Pemerintah RI sebagai wilayah pengembangan utama. Namun hingga kini ternyata masih banyak desa-desa kecil di Propinsi NTT yang tergolong sulit sekali untuk berkembang, khususnya dalam hal pemenuhan kebutuhan air bersihnya.

Propinsi NTT mempunyai kondisi alam yang cukup berat, khususnya dalam hal potensi sumber daya airnya. Propinsi ini dikenal sebagai daerah yang kering, curah hujannya terkecil dibandingkan dengan seluruh daerah di Indonesia, dan tambahan lagi kondisi tanahnya kering dan berbatu-batu serta di sebagian wilayah bertanah kapur. Karena kondisi daerah yang penuh dengan keterbatasan daya dukung alam, terutama sumber daya air, maka masyarakat penduduknya pun banyak yang masih tertinggal perkembangannya dalam berbagai sektor kehidupan. Masalah tidak terpenuhinya kebutuhan air bersih masyarakat menjadi semakin parah pada musim-musim kemarau. Bila terjadi kemarau panjang, maka pasti akan merupakan bencana besar bagi propinsi seperti NTT ini. Pada tahun 2005 dimana musim kemarau panjang terjadi di wilayah ini, begitu banyak permasalahan lingkungan timbul dan mengakibatkan penderitaan masyarakat di propinsi ini, terutama masyarakat yang tinggal di daerah pedesaan. Waterborne desease, yaitu penyakit yang ditimbulkan oleh karena buruknya kondisi pemenuhan kebutuhan air bersih, berkembang menjadi epidemi di banyak desadesa tertinggal di propinsi NTT ini.

Sehubungan dengan masalah tersebut di atas, maka dibutuhkan pengkajian awal untuk melihat permasalahan secara lebih terinci, khususnya masalah pemenuhan kebutuhan air bersih di desa-desa yang tergolong tertinggal. Pengkajian ini merupakan langkah permulaan yang harus ditempuh untuk menentukan kegiatan selanjutnya, seperti penelitian sistem pengelolaan sumber daya air atau yang sudah mengarah kepada sistem pengelolaan air bersih untuk masyarakat pedesaan. Selanjutnya baru kemudian dapat dilakukan penerapan teknologi pengolahan atau pengelolaan sumber daya air. Penerapan teknologi ini harus pula disesuaikan dengan tingkat kondisi sosial, budaya dan ekonomi masyarakatnya. Dengan demikian pemanfaatan sistem teknologi tersebut dapat optimal dan bahkan berkembang, meluas atau memasyarakat.

\subsection{Tujuan}

Tujuan utama kajian ini adalah untuk mengidentifikasi masalah pemenuhan kebutuhan air bersih masyarakat di tiga desa di Kabupaten Ende. Tujuan kedua yaitu mencari pemecahan masalah tersebut dan secara terbatas 
memberikan saran dalam upaya mengatasi masalah tersebut.

\subsection{Ruang Lingkup} adalah :

Ruang lingkup dalam penelitian ini

a. Permasalahan yang dikaji adalah terbatas pada sistem penyediaan air bersih bagi masyarakat pedesaan.

b. Batasan lokasi survai adalah di tiga desa tertinggal di Kabupaten Ende, yaitu Desa Detukeli di Kecamatan Maurole, Desa Ndetundora I dan Ndetundora II yang terletak di Kecamatan Ende.

\subsection{Metodologi}

Data sekunder diperoleh dari laporan di Kantor Kepala Desa setempat. Untuk data primer dilakukan dengan metode survai lapangan langsung ke desa-desa yang menjadi obyek kajian. Sementara itu penentuan obyek lokasi desa yang disurvai adalah berdasarkan beberapa kriteria sebagai berikut :

- Belum pernah terjangkau program kegiatan penyediaan sarana dan prasarana untuk pemenuhan kebutuhan air bersih, baik dari pemerintah atau pun dari bantuan pihak swasta atau luar negeri.

- Mempunyai masalah yang tergolong berat atau tingkat kesulitan tinggi dalam hal pemenuhan kebutuhan air bersih.

- Mempunyai potensi yang cukup (sumber daya alam, manusia, sosial, ekonomi dan budaya) untuk mengadaptasi penerapan teknologi tepat guna dalam bidang pengelolaan dan pengolahan air.

\section{HASIL SURVAI}

\subsection{Gambaran Umum}

Berdasarkan data dari Aus-Aid (Tahun 1999) dapat dilihat bahwa masih banyak desadesa miskin yang tersebar di Kabupaten Ende (lihat Tabel 1 pada lampiran). Untuk dua kecamatan saja, yaitu Kecamatan Ende dan Kecamatan Maurole, terdapat daftar yang menunjukkan bahwa terdapat 25 desa miskin yang masih kesulitan air bersih, diantaranya adalah Desa Detukeli, Desa Ndetundora I dan Ndetundora II.

\section{a. Desa Detukeli}

Desa Detukeli terletak $57 \mathrm{~km}$ di sebelah utara dari lbu Kota Kabupaten (Ende) dan dapat ditempuh dengan kendaraan dalam waktu kurang lebih satu jam. Morfologi daerah berbukit-bukit dengan ketinggian berkisar $700-1000 \mathrm{~m}(\mathrm{dml}=$ di atas muka laut). Luas wilayah $56,77 \mathrm{~km}^{2}$. Pemukiman terbagi dalam 4 dusun yang terpencar di antara perbukitan. Jumlah penduduk Desa Detukeli adalah 1789 jiwa dengan 378 kk (Tahun 2006). Menurut informasi kepala desa, Dusun I berjumlah 663 jiwa dengan 141 kk, Dusun II berjumlah 670 jiwa dengan $141 \mathrm{kk}$, Dusun III berjumlah 257 jiwa dengan 55 kk dan Dusun IV sekitar 199 jiwa dengan 41 kk.

Fasilitas air minum yang tersedia adalah sistem perpipaan gravitasi. Ada dua tempat yang memakai sistem gravitasi yaitu Dusun 1, Dusun 2 dan Dusun 3. Ukuran pipa yang dipakai 2 inci dan 3 inci terbuat dari pipa besi galvanis. Jarak sumber air baku berkisar $200 \mathrm{~m}$ - 3 kilometer dari lokasi pemukiman. Hanya saja debit air sumbernya terlalu kecil, yaitu sekitar 0,5 liter/detik, sehingga tidak mencukupi untuk kebutuhan penduduk. Di samping itu distribusi air dari bak penampungan ke penduduk belum memadai, masih menggunakan selang dan belum merata.

\section{b. Ndetundora I}

Desa ini terletak sekitar $11 \mathrm{~km}$ dari Ende atau kalau menggunakan kendaraan dapat ditempuh dalam waktu 35 menit. Wilayahnya tidak terlalu luas hanya sekitar $11,51 \mathrm{~km}^{2}$ dan $74 \%$ dari wilayahnya merupakan daerah yang berlereng curam $(>40 \%)$. Desa ini dihuni oleh 2.029 jiwa dengan $339 \mathrm{kk}$.

\section{c. Ndetundora II}

Desa ini terletak $10 \mathrm{~km}$ dari Ende atau kalau menggunakan kendaraan dapat ditempuh dalam waktu 30 menit. Wilayah desa ini tidak terlalu luas, yaitu hanya $7,15 \mathrm{~km}^{2}$, lebih kecil dari pada Desa Ndetundora I. Sebagian (70\%) wilayah desa ini juga merupakan daerah yang berlereng curam (>40\%). Jumlah penduduk 1.342 jiwa (268 kk) tersebar di daerah yang relatif datar dan dekat jalan besar. Mata pencaharian sebagian besar penduduk adalah petani dan buruh tani.

\subsection{Permasalahan Penyediaan Air Bersih}

\section{a. Desa Detukeli}

Sumber air bersih yang ada umumnya terletak jauh di bawah $( \pm 100$ meter) pemukiman, jaraknya cukup jauh (3 kilometer) dan debit airnya tidak terlalu besar. Pada musim kemarau sumber air ini menjadi sumber air andalan Desa Detukeli, walaupun lokasinya cukup sulit untuk dijangkau. Sumber air potensial terletak di atas 
perbukitan sebelah barat dengan jarak $7 \mathrm{~km}$. Perbedaan elevasi antara sumber air dan lokasi pemukiman adalah sekitar 50 meter.

Debit air cukup besar dan berdasarkan hasil pengukuran kasar di lapangan diperoleh sekitar 7 liter/detik. Jika air ini dimanfaatkan maka Dusun I, II, dan III dapat terpenuhi kebutuhan airnya, sedangkan dusun IV terletak lebih tinggi dari sumber air, sehingga memerlukan upaya khusus untuk mengangkat air. Jika sumber air ini dimanfaatkan dapat meningkatkan kesejahteraan masyarakat desa Detukeli.

\section{b. Ndetundora I}

Sumber air bersih berasal dari kali yang berjarak kurang lebih satu kilometer, ke arah selatan. Sumber air ini juga digunakan oleh PDAM sebagai sumber air minum dengan kapasitas 1,5 liter per detik. Air dari PDAM ini dipompa ke desa Ndetundora I dan II. Namun demikian belum semua penduduk mendapat pelayanan air minum karena kapasitas belum memenuhi. Tenaga penggerak pompa menggunakan genset $15 \mathrm{kw}$. Padahal untuk keperluan pemompaan hanya sekitar 200 watt, sehingga tenaga listrik masih surplus. Menurut informasi kepala desa (Bapak Mando) sekitar 300 meter dari lokasi intake PDAM ada sumber air pertemuan dua sungai yang kapasitasnya besar. Jika hal ini dimanfaatkan, akan dapat menunjang kebutuhan air untuk desa Ndetundora I dan II.

Sumber air lain ada di desa Tumberabu, jaraknya $9 \mathrm{~km}$ dengan kapasitas yang tidak terlalu besar, yaitu 3 liter/detik dan mata air Pingga, jaraknya $20 \mathrm{~km}$ dengan kapasitas yang belum diukur tetapi lebih besar dari yang ada $\mathrm{d}$ Tumberabu.

\section{c. Ndetundora II}

Sumber air bersih untuk desa Ndetundora II adalah kali kecil dengan beberapa mata air yang terdapat disekitarnya. Sebelum kejadian gempa bumi (12 Desember 1991), mata air disini cukup besar, tetapi setelah kejadian gempa tersebut lokasi mata air longsor dan air yang keluar mengecil. Untuk kebutuhan air minum, mandi dan mencuci, kali kecil yang terletak 500 meter dari lokasi pemukiman merupakan andalan bagi penduduk. Pelayanan PDAM yang berada di lokasi Ndetundora I juga sampai ke Desa Ndetundora II, tetapi belum semua penduduk mendapat pelayanan. Keadaan di desa ini cukup memprihatinkan dan perlu untuk mendapat prioritas bantuan pelayanan air bersih.

\subsection{Alternatif Pemecahan Masalah}

Secara keseluruhan Kabupaten Ende cukup kaya akan sumber air permukaan, hanya masalahnya tempat penduduk bertempat tinggal sering tidak seiring dengan tempat sumber air berada, sehingga untuk memanfaatkan air memerlukan tenaga atau energi ekstra. Kebiasaan untuk tinggal di suatu tempat dan mengumpul membuat sulit untuk pindah ke tempat lain yang mungkin lebih baik sumber airnya. Ketua adat dalam hal tertentu masih memegang peranan penting dalam mengambil keputusan.

Masyarakat Desa Detukeli sudah lama mengharapkan datangnya bantuan untuk penyediaan sarana air bersih. Ditinjau dari sarana air yang ada, ternyata memang masih kurang dan memerlukan bantuan sarana air bersih. Dari pengamatan pada waktu survey ke lokasi sumber air di bagian bawah yang berjarak 3 kilometer dapat terlihat bahwa sumber air tersebut sulit untuk dimanfaatkan, karena terlalu kecil debitnya dan energi untuk mengangkatnya terlampau mahal.

Sumber air pontensial terdapat di sebelah timur desa Detukeli berjarak $7 \mathrm{~km}$. Sumber air tersebut terletak pada elevasi $850 \mathrm{~m}$ (dml) dengan kapasitas $5-7$ liter/detik, sedangkan desa Detukeli sendiri terletak pada ketinggian $800-815 \mathrm{~m}$ (dml), sehingga memungkinkan untuk pembuatan sistem perpipaan dengan gravitasi. Hanya saja khusus untuk dusun IV yang letaknya lebih tinggi sekitar 25 meter dari mata air memerlukan pemanfaatan pompa hidram. Untuk membangun sistem ini memerlukan dana sekitar Rp.1.826.000.000,(lihat Tabel 2 pada lampiran).

\section{KESIMPULAN DAN SARAN}

Berdasarkan pada yang telah diungkapkan dalam pembahasan, maka dapat disimpulkan dan sekaligus disarankan seperti berikut ini :

1. Secara umum Kabupaten Ende cukup kaya akan sumber air bersih. Banyak kasus kekurangan atau kesulitan air di Kabupaten ini akibat lokasi pemukiman yang terletak di atas lokasi mata air, sehingga untuk pengangkatan air membutuhkan tenaga atau energi dan hal tersebut berarti membutuhkan biaya.

2. Jika investasi sarana air bersih masih dirasa mahal, perlu dipertimbangkan untuk relokasi pemukiman ke tempat yang banyak sumber airnya.

3. Desa Detukeli letaknya diperbukitan, sarana air bersih yang dibangun secara swadaya terasa masih kurang memadai karena debitnya terlalu kecil. Untuk mencukupi 
kebutuhan air diperlukan upaya untuk memanfaatkan sumber air yang letaknya kurang lebih $7 \mathrm{~km}$ dari desa Detukeli. Untuk menangkap mata air tersebut lebih baik menggunakan sistem gravitasi, kecuali beberapa tempat (dusun IV) mungkin memerlukan pompa hidram.

4. Desa Ndetundora I dan II sudah mendapat pelayanan air bersih dari PDAM Kabupaten Ende. Masalah yang dihadapi di lapangan adalah pompa air baku terlalu berat karena harus memompa dari sungai sampai ke konsumen dan debit air baku lebih kecil dari kapasitas pompa, sehingga pada musim kemarau sering terganggu. Untuk optimalisasi perlu penambahan kapasitas air baku dan bak penampung yang mencukupi kebutuhan air bersih bagi 2 desa tersebut.

5. Untuk mengatasi permasalahan air bersih di desa-desa yang ditinjau di Kabupaten Ende pada umumnya dapat memilih alternatifalternatif sebagai berikut :

a. Melakukan reboisasi atau penghutanan kembali kawasan hulu di daerah pebukitan dan lereng-lerengnya. Hal ini dimaksudkan untuk meningkatkan potensi sumber daya air.

b. Pembangunan atau pembuatan embung kecil. Dalam hal ini juga termasuk rehabilitasi embung yang sudah ada dan mengoptimalkan dari segi OM (Operation \& Management).

c. Pembangunan atau pembuatan bendungan kecil bagi mata air potensial dan kemudian baru dilakukan pemompaan air, serta kemudian dilengkapinya dengan sistem distribusi primer atau bahkan sampai sekunder.

d. Pemanfaatan air tanah dangkal atau pun air tanah dalam.

\section{DAFTAR PUSTAKA}

1. NN, "Aus-Aid Report on Clean Water Problems in Small Villages", Dinas PU, Propinsi NTT - AusAid, 1999.

2. NN, "Laporan Monografi Kecamatan Ende \& Maurole", Kantor Kecamatan Ende dan Kantor Kecamatan Maurole, 2005.

3. NN, "Water Basin in NTT", Dinas PU Propinsi NTT, 2000. 


\section{LAMPIRAN}

Tabel 1: Data air minum/bersih pedesaan

\begin{tabular}{|c|c|c|c|c|}
\hline NO & KECAMATAN & DESA & RANKING Aus-AID & KETERANGAN \\
\hline 1. & ENDE: & $\begin{array}{l}\text { - Tomberabu II } \\
\text { - Borokanda } \\
\text { - Riaraja } \\
\text { - Gheoghama } \\
\text { - Ndetundora II } \\
\text { - Ndetundora I } \\
\text { - Rukuramba } \\
\text { - Wologai } \\
\text { - Tomberabu I } \\
\text { - Mbotutenda }\end{array}$ & $\begin{array}{l}316.85 \\
265.40 \\
238.82 \\
222.53 \\
216.12 \\
201.86 \\
190.72 \\
189.77 \\
189.58 \\
173.00\end{array}$ & $\begin{array}{l}\text { Aus-AID } \\
\text { Aus-AID } \\
\text { PU Cipta Karya } \\
\text { Aus-AID } \\
15 \text { Km Lowo Poa } \\
\text { Aumati } \\
\text { PU Cipta Karya } \\
\text { PU Cipta Karya } \\
\text { Depsos } \\
\text { PU Cipta Karya/LKMD }\end{array}$ \\
\hline 2. & MAUROLE & $\begin{array}{l}\text { - Detukeli } \\
\text { - T o u } \\
\text { - Hangalande } \\
\text { - Loboniki } \\
\text { - Taniwoda } \\
\text { - Kotabaru } \\
\text { - Aewora } \\
\text { - Ranokolo } \\
\text { - Kanganara } \\
\text { - Watunggere } \\
\text { - Maurole } \\
\text { - Mausambi } \\
\text { - Niopanda } \\
\text { - Wolomuku } \\
\text { - Nggesa }\end{array}$ & $\begin{array}{l}343.41 \\
333.74 \\
310.33 \\
297.53 \\
289.97 \\
274.04 \\
273.41 \\
238.51 \\
233.88 \\
229.29 \\
207.05 \\
197.35 \\
182.67 \\
176.12 \\
159.65\end{array}$ & $\begin{array}{l}\text { PU Cipta Karya Plan } \\
\text { AUS - Aid } \\
\text { AUS - Aid } \\
\text { AUS - Aid } \\
\text { Dian Desa } \\
\text { Resettlement }\end{array}$ \\
\hline
\end{tabular}


Tabel 2 : Rencana Anggaran Biaya (RAB) untuk pengadaan dan pemasangan jaringan Perpipaan di Desa Detukeli.

\begin{tabular}{|c|c|c|c|c|}
\hline No. & Uraian & Volume & $\begin{array}{l}\text { Harga Satuan } \\
\text { (Rp) }\end{array}$ & $\begin{array}{c}\text { Jumlah Harga } \\
\text { (Rp) }\end{array}$ \\
\hline 1 & 2 & 3 & 4 & 5 \\
\hline \multirow[t]{2}{*}{$\mathrm{I}}$. & \multirow[t]{2}{*}{$\begin{array}{l}\text { Pekeriaan Persiapan } \\
\text { - Pembersihan Lokasi } \\
\text { - Lok Kerja }\end{array}$} & \multirow[t]{2}{*}{$\begin{array}{l}1 \mathrm{LS} \\
1 \mathrm{LS}\end{array}$} & \multirow{2}{*}{$\begin{array}{r}5.000 .000 \\
11.000 .000 \\
\text { Jumlah I }\end{array}$} & $\begin{array}{r}5.000 .000 \\
11.000 .000 \\
\end{array}$ \\
\hline & & & & 16.000 .000 \\
\hline \multirow[t]{2}{*}{ II. } & \multirow[t]{2}{*}{$\begin{array}{l}\text { Pekerjaan Intake } \\
\text { - Bronkaptering } \\
\text { - Reservoir }\end{array}$} & \multirow[t]{2}{*}{$\begin{array}{l}1 \text { Unit } \\
1 \text { Unit }\end{array}$} & \multirow{2}{*}{$\begin{array}{l}10.000 .000 \\
20.000 .000 \\
\text { Jumlah II }\end{array}$} & $\begin{array}{l}10.000 .000 \\
20.000 .000\end{array}$ \\
\hline & & & & 30.000 .000 \\
\hline \multirow[t]{2}{*}{ III. } & \multirow{3}{*}{$\begin{array}{l}\text { Pipa Transmisi (4”) } \\
\text { - Pipa GIP } \\
\text { - Pompa Hidran (3") } \\
\text { - Accessories : Sock, Water moor, } \\
\text { Knee, Stop Valve,Reducer, Gibout, dll. } \\
\text { Pipa Distribusi (3") }\end{array}$} & \multirow[t]{2}{*}{$\begin{array}{l}500 \mathrm{M} \\
100 \mathrm{btg} \\
2 \text { buah } \\
1 \mathrm{LS}\end{array}$} & $\begin{array}{r}800.000 \\
10.000 .000 \\
15.000 .000\end{array}$ & $\begin{array}{l}80.000 .000 \\
20.000 .000 \\
15.000 .000\end{array}$ \\
\hline & & & \multirow{3}{*}{$\begin{array}{r}\text { Jumlah III } \\
\\
600.000 \\
100.000 .000\end{array}$} & 115.000 .000 \\
\hline \multirow[t]{3}{*}{ IV. } & & \multirow{3}{*}{$\begin{array}{l}5.750 \mathrm{M} \\
960 \mathrm{btg} \\
1 \mathrm{LS}\end{array}$} & & \\
\hline & \multirow{4}{*}{$\begin{array}{l}\text { - Pipa GIP } \\
\text { - Accessories : Sock, Water moor, } \\
\text { Niple, Knee, Stop Valve,Reducer, } \\
\text { Gibout,Ventilasi Udara (2") dll. } \\
\\
\text { Pipa Distribusi ( 2") } \\
\text { - Pipa GIP } \\
\text { - Accessories : Sock, Water moor, } \\
\text { Niple, Knee, Valve,Reducer, Gibout, dll. }\end{array}$} & & & $\begin{array}{l}576.000 .000 \\
100.000 .000\end{array}$ \\
\hline & & & \multirow{2}{*}{\begin{tabular}{|r|} 
Jumlah IV \\
\\
500.000 \\
80.000 .000
\end{tabular}} & 676.000 .000 \\
\hline \multirow[t]{2}{*}{ V. } & & \multirow[t]{2}{*}{$\begin{array}{c}5.750 \mathrm{M} \\
960 \mathrm{btg} \\
1 \mathrm{LS}\end{array}$} & & $\begin{array}{r}480.000 .000 \\
80.000 .000\end{array}$ \\
\hline & & & \multirow[b]{2}{*}{$\begin{array}{r}\text { Jumlah V } \\
\\
400.000 \\
15.000 .000\end{array}$} & 560.000 .000 \\
\hline \multirow[t]{2}{*}{ VI. } & \multirow[t]{2}{*}{$\begin{array}{l}\text { Pipa Distribusi (1”) } \\
\text { - pipa GIP } \\
\text { - Accessories : Sock, Water moor, } \\
\text { Niple, Knee, Valve,Reducer, Gibout, dll. }\end{array}$} & \multirow[t]{2}{*}{$\begin{array}{c}1.000 \mathrm{M} \\
170 \mathrm{btg} \\
1 \mathrm{LS}\end{array}$} & & $\begin{array}{l}68.000 .000 \\
15.000 .000\end{array}$ \\
\hline & & & Jumlah VI & 83.000 .000 \\
\hline \multirow[t]{2}{*}{ VII. } & \multirow[t]{2}{*}{$\begin{array}{l}\text { Pipa Tersier (3/4”) } \\
\text { - pipa GIP } \\
\text { - Accessories : Sock, Water moor, } \\
\text { Niple, Knee, Valve,Reducer, Gibout, dll. }\end{array}$} & \multirow[t]{2}{*}{$\begin{array}{c}1.500 \mathrm{M} \\
250 \mathrm{btg} \\
1 \mathrm{LS}\end{array}$} & $\begin{array}{r}250.000 \\
15.000 .000\end{array}$ & $\begin{array}{l}62.500 .000 \\
15.000 .000\end{array}$ \\
\hline & & & Jumlah VII & 77.500 .000 \\
\hline \multirow[t]{2}{*}{ VIII. } & \multirow[t]{2}{*}{$\begin{array}{l}\text { Pipa Tertier (1/2") } \\
\text { - pipa GIP dia 1/2" } \\
\text { - Accessories : Sock, Water moor, } \\
\text { Niple, Knee, Valve,Reducer, Gibout, dll. }\end{array}$} & \multirow[t]{2}{*}{$\begin{array}{c}1.500 \mathrm{M} \\
250 \mathrm{btg} \\
1 \mathrm{LS}\end{array}$} & $\begin{array}{r}150.000 \\
10.000 .000\end{array}$ & $\begin{array}{l}37.500 .000 \\
10.000 .000\end{array}$ \\
\hline & & & Jumlah VIII & 47.500 .000 \\
\hline \multirow[t]{4}{*}{ IX. } & \multirow{4}{*}{$\begin{array}{l}\text { Rencana Ressevoir } \\
\text { - Ressevoir } 30 \mathrm{~m}^{3} \\
\text { - Ressevoir } 15 \mathrm{~m}^{3} \\
\text { Supervisi \& Commissioning }\end{array}$} & \multirow[t]{2}{*}{$\begin{array}{l}1 \text { unit } \\
2 \text { unit }\end{array}$} & \multirow{4}{*}{$\begin{array}{l}15.000 .000 \\
7.500 .000 \\
\text { Jumlah IX } \\
\text { Jumlah X } \\
\text { Jumlah Total } \\
\text { Ppn } 10 \% \\
\text { TOTAL }\end{array}$} & $\begin{array}{l}15.000 .000 \\
15.000 .000\end{array}$ \\
\hline & & & & $\begin{array}{l}30.000 .000 \\
25.000 .000\end{array}$ \\
\hline & & & & $\begin{array}{r}1.660 .000 .000 \\
166.000 .000\end{array}$ \\
\hline & & & & 1.826 .000 .000 \\
\hline
\end{tabular}

